\begin{tabular}{|c|c|c|}
\hline Beitr. Ent. & Keltern & ISSN 0005-805X \\
\hline $\mathbf{6 2}(2012) 2$ & S. $427-445$ & 20.12 .2012 \\
\hline
\end{tabular}

\title{
Contribution to the taxonomy and nomenclature of Entiminae from the Palaearctic region and South Africa
}

\section{(Coleoptera: Curculionidae)}

With 57 figures

Nikolai N. Yunakov and Klaus-Dieter Klass

\section{Summary}

Synonymy is newly established for the following taxon names: Ellimenistes BoHeman, $1843=$ Pimelorrhinus Reitter, 1915, syn. n.; Ellimenistes setulosus Fånraeus, 1871 = Pimelorrhinus globatus Reitter, 1915, syn. n.; Polydrusus subgen. Eudipnus C. G. Thomson, 1859 = Eudipnoidius Apfelbeck, 1898 syn. n.; Polydrusus subgen. Eustolus C. G. Thomson, 1859 = Tylodrusinus Reitter, 1916, syn. n.; Polydrusus impar Gozis, $1882=$ P. impar vranicensis ReItTer, 1905, syn. n.; Chiloneus SCHOenherR, $1842=$ Chilonorrhinus Reitter, 1915, syn. n.; Wittmerella Pesarini, 1973 = Sciaphilomorphus Alonso-Zarazaga \& Lyal, 1999 syn. n. New combinations are proposed: Otiorhynchus (Eunihus) pisidicus (Magnano, 2001) comb. n. from Parameira Seidlitz, 1868; Ellimenistes globatus Reitter, 1915, comb. n. from Pimelorrhinus Reitter; Chiloneus sitonoides (Reitter, 1915), comb. n., Chiloneus corcyreus (Penecke, 1935), comb. n., Chiloneus aliquoi (Pesarini, 1974), comb. n., and Chiloneus sahlbergi (ReItTer, 1915), comb. n. from Chilonorrhinus Reitter; Wittmerella aurosa (Boheman, 1845) comb. n. and W. sulcirostris (Chevrolat, 1860) comb. n. from Sciaphilomorphus Alonso-Zarazaga \& Lyal. Type species designation: for Chilonorrhinus Reitter, 1915 (= Chiloneus SchoenHerr) - Chilonorrhinus sitonoides ReitTer, 1915.

\section{Zusammenfassung}

Synonymie wird für die folgenden Taxonnamen neu etabliert: Ellimenistes BoHEman, 1843 = Pimelorrhinus ReItTer, 1915, syn. n.; Ellimenistes setulosus FÅHraeus, 1871 = Pimelorrhinus globatus ReItTer, 1915, syn. n.; Polydrusus subgen. Eudipnus C. G. Thomson, 1859 = Eudipnoidius Apfenbeck, 1898 syn. n.; Polydrusus subgen. Eustolus C. G. Thomson, 1859 = Tylodrusinus Reitter, 1916, syn. n.; Polydrusus impar Gozis, 1882 = P. impar vranicensis ReITter, 1905, syn. n.; Chiloneus SCHOENHERR, $1842=$ Chilonorrhinus ReITter, 1915, syn. n.; Wittmerella Pesarini, 1973 = Sciaphilomorphus Alonso-Zarazaga \& Lyal, 1999 syn. n. Neue Kombinationen werden vorgeschlagen: Otiorhynchus (Eunihus) pisidicus (Magnano, 2001) comb. n. aus Parameira Seidutiz, 1868; Ellimenistes globatus Reitter, 1915, comb. n. aus Pimelorrhinus Reitter; Chiloneus sitonoides (Reitter, 1915), comb. n., Chiloneus corcyreus (Penecke, 1935), comb. n., Chiloneus aliquoi (Pesarini, 1974), comb. n., und Chiloneus sahlbergi (Reitter, 1915), comb. n. aus Chilonorrhinus Reitter; Wittmerella aurosa (Boheman, 1845) comb. n. und W. sulcirostris (Chevrolat, 1860) comb. n. aus Sciaphilomorphus Alonso-Zarazaga \& Lyal. Designierung von Typusarten: für Chilonorrhinus Reitter, 1915: 187 (= Chiloneus SCHoenherr) - Chilonorrhinus sitonoides Reitter, 1915.

Key words

Curculionidae, Entiminae, new synonym, new combination. 


\section{Introduction}

Entiminae is one of the most speciose subgroups of the Curculionidae (weevils). Over 12,000 species have been described that are classified into ca 1,350 genera and 54 tribes (Thompson 1992; Alonso-Zarazaga \& Lyal 1999). The group includes a few extremely diverse genera, such as the mainly Palaearctic Otiorhynchus Germar, 1822, Polydrusus Germar, 1817, and Myllocerus SchoenherR, 1823. While there are several experts worldwide that cover the diversity of Entiminae and study the fields relevant to the systematic exploration of the group, their working capacities have been much too limited for this large group, and in many corners Entiminae systematics is still in the status of chaos. In present times taxonomic work on Entiminae (as in other groups of beetles) includes - or at least should include - thorough and detailed work on the morphological character systems that yield features distinguishing species. Important character systems of this kind are the male and female genitalia, the structures at the distal ends of the tibia, the ventral side of the head capsule, the mouth parts, and the chaetotaxy of the fronto-epistomal area and mouth parts. There has been a considerable amount of revisionary work following this approach in recent decades such as MarshaLl $(1942,1943)$ on Embrithini, Oberprieler (1988) on Tanyrhynchini, Korotyaev \& Meleshoo (1997) on Polydrusus, Morimoto et al. (2006) on Phyllobiini and Cyphicerini, Yunakov (2004) on Parameira, and Yunakov \& Korotyaev (2008) on Araxia. The exploration of Entiminae systematics should also include phylogenetic work, based both on morphological and molecular data. Developments in this field, however, are still at their very beginnings. There are hardly any molecular data yet, and no phylogenetic analysis of Entiminae as a whole or of any subgroup.

The Holarctic Entiminae fauna has long received considerable attention by experts, yet the status of its systematisation has remained quite insufficient. This problem abounds for Entiminae diversity of the other zoogeographical regions. Numerous Entiminae species have been described from areas outside the Holarctic in the last 200 years. According to the poor status of morphological knowledge on the group, and also due to typological, pre-phylogenetic reasoning, these were placed in some new genera, as they were considered different from those that have been known before (or from what the describing author knew!). Or, the new taxa were put into some wellknown genus from the Holarctic due to some kind of superficial resemblance. Notably, such similarity can well result from adaptation to similar habitats or life histories (such as subterranean life) or from a shared reduction of hind wings - both phenomena being widespread in Entiminae. Often members of such exotic taxa have never been subjected to any critical examination by an expert up to date. Therefore, when one starts to study the morphology of specimens of such taxa more closely, it is not unusual to find features that suggest a systematic position that differs dramatically from the traditional view. In such cases, either dramatic morphological differences from the surmised "congeneric" taxa may become evident. Or, alternatively, one may find out that specimens from such an exotic taxon are very similar to some other genus or even to a particular species of this other genus, suggesting its inclusion into that genus or even the synonymisation of species names. In many such cases, a major taxonomic change is then required for the exotic taxon concerned, often across tribes.

Comparative morphological studies of poorly known Entiminae genera, done in recent years by the first author, revealed a number of cases where a described taxon was evidently closely related to another taxon of varied systematic distance, or conspecific with some other taxon. The study of these cases included the examination of the type material. Important results from this work are the clarification of the systematic position of several "floating" genera, and the demonstration that certain "taxa" are conspecific (leading to synonymising the names concerned). Most of the 
cases here discussed concern the tribal complex of brachyderoid entimines, which comprises the tribes Brachyderini, Polydrusini, and especially Sciaphilini. These species-rich tribes include, on the one hand, some speciose genera (e.g. Polydrusus) that are not based on sound morphological knowledge and synapomorphies but are the product of typological approaches to taxonomy combined with consideration of only superficial morphological features. On the other hand, these tribes include a number of small, often monotypic, and often poorly known, "floating" genera of unclear relationships.

\section{Material and methods}

\section{Sources of specimens:}

This study is based on type material from the collections of the following museums:

KUMN Museum of Nature, Kharkiv State University

MTD Museum für Tierkunde, Senckenberg Naturhistorische Sammlungen Dresden

MTMB Magyar Természettudományi Muzeum, Budapest

NMB Naturhistorisches Museum, Basel

SZMN Institute of Animal Systematics and Ecology, Siberian Zoological Museum, Novosibirsk

ZIN Zoological Institute, St. Petersburg

ZMUC Zoological Museum, University of Copenhagen

\section{Terminology:}

Details of external and internal morphology are generally termed in accordance with OBERPRIELER (1988) and Мовімото et al. (2006). In addition, some specific terms for the description of tibial apices and abdominal segments have been adopted from Thompson (1992), and terms for male and female genitalia from ArZanov (2003) and WanAT (2007).

\section{Measurements:}

All measurements have been done with an ocular-micrometer. Body length was measured from the anterior margin of the compound eye to the apex of the elytra, and the length of the rostrum from the apex of the rostrum to the anterior edge of the pronotum at midline. Width of the rostrum is the distance between the lateral extremities of the left and right pterygia. A set of indices was widely employed for a characterisation of the shape of body parts such as ratio of width between eyes versus longitudinal eye diameter (FW/ELD), pronotum length versus pronotum width $(\mathrm{PL} / \mathrm{PW})$, and elytra length versus elytra width (EL/EW).

\section{Dissection:}

Observations and dissections of specimens were performed with a Leica MZ8 stereo microscope; genitalia of both sexes were examined using an Olympus BX41 compound microscope (magnification 20-200x). Beetles were soaked in warm $10 \% \mathrm{C}_{2} \mathrm{H}_{5} \mathrm{OH}$ solution with detergent to clean legs, antennae, and the body surface including their vestiture; all these parts are usually coated with soil particles. The abdomen was extracted and the posterior part containing the alimentary canal and genitalia was cleared in hot $10 \% \mathrm{KOH}$ solution, washed in distilled water, and dehydrated sequentially using $60 \%, 80 \%$, and $96 \%$ ethanol solutions. The dorsal wall of abdominal segments, gut, sperm duct, and spermathecal gland were stained with ChlorazolBlack-E. 


\section{Storage:}

For long-term storage, all genital structures were either put in microvials with glycerol then attached to the pin, or put into a drop of water-soluble inclusive synthetic resin or Euparal on a piece of cardboard then pinned below the specimen. Beetles were mounted on cardboard and pinned by standard means.

\section{Imaging:}

Illustrations were drawn from objects in glycerine using a grid-ocular, and were edited with Corel Draw 11 with highlighting of taxonomically important details. Photos of specimens and morphological details were taken with a digital camera. Merging of layers was done with Helicon Focus software.

\section{Results and discussion}

\subsection{Tribe Embrithini Marshall, 1942}

\section{Ellimenistes BOHEMAN in SCHOENHERR C. J. 1843}

Pimelorrhinus ReItTer, 1915: 116, syn. n.

\section{Ellimenistes setulosus FÅHRAEUs, 1871}

Pimelorrhinus globatus ReItTer, 1915, syn. n.

\section{Taxonomic notes:}

The original description of Pimelorrhinus and of its sole species P. globatus was based on a single male (Fig. 1) with the label 'Ins. Rhodus' (Fig. 2). No further species were assigned later to Pimelorrhinus, so that the genus has remained monotypic. ReITter (1915a) attributed Pimelorrhinus to the tribe Holcorrhinini because it shares with those a transversal sulcus on the epifrons beyond the eyes. In fact, the type specimen must be transferred to the South African genus Ellimenistes BoH., of which 36 species have become described. Moreover, there are no differences in external morphology and male genitalia between the type specimen of Pimelorrhinus globatus RTT. and Ellimenistes setulosus FÅHR. Thus, a new synonymy is proposed here for Ellimenistes setulosus FÅHraeus, 1871 and Pimelorrhinus globatus Reitter, 1915.

'Ins. Rhodus' could be interpreted as the Dodecanese island in Aegean Sea bearing this name. However, there is no further record for either name from the Mediterranean region. Thus either the "Pimelorrhinus globatus" specimen was introduced to this island accidentally, or the specimen is mislabeled. One possible source for mislabeling is the similarity of spelling of 'Rhodus' and 'Rhodes', a university in Grahamstown (established in 1904) in the Eastern Cape province, where Ellimenistes setulosus was described from (FÅHraeus 1871).

\section{Type material:}

Pimelorrhinus globatus: Holotype, male (MTMB): 'Ins. Rhodus' / 'Pimelorrhinus globatus m. 1915. Type' / 'Coll. Reitter' / 'Monotypus Pimelorrhinus globatus Reitter 1915' / 'Ellimenistes setulosus Fåhr., Yunakov det. 2009’.

Other material examined:

South Africa: $10^{\star}, 1$ ㅇ (MTMB) "S. Africa/ Natal"; $10^{\star}$ (ZIN) "South Africa (Natal)"; $20^{\star} 0^{\star} 1$ ㅇ (KUMN) "Port Natal [= Durban]/ Deyrolle [leg.]". 


\title{
3.2. Tribe Otiorbynchini SCHOENHERr, 1826
}

\section{Otiorhynchus Germar, 1824}

\section{Subgenus Eunibus REITTER, 1912}

Otiorhynchus (Eunibus) pisidicus (Magnano), comb. n.

\author{
Magnano, 2003: 245 (Parameira)
}

\section{Taxonomic notes:}

When describing this species, Magnano (2003) assigned it to the genus Parameira Seiduitz, 1868, which includes 7 species distributed mostly over southern Europe and P. gebleri Faust, 1893 from southern Siberia. Reasons for this assignment were not given. Four paratypes of Parameira pisidica were examined and compared both with Parameira species and Otiorhynchus (Eunihus) species. First, there are no significant differences between P. pisidica and Otiorhynchus (Eunihus). Second, P. pisidica does not show any of the significant apomorphies of Parameira, such as the epistomal carina surrounding the epistome and the posterior squamulate fringe of the pronotum. Its elytra are pyriform as in Eunihus but not oblong-ovate as in Parameira.

\section{Parameira SeIDlitz, 1868: 26}

[type species: Stomodes rudis BoHeman, 1843, by subsequent designation in Yunakov 2004: 1284]

\section{Parameira (Lepidostomodes) gebleri FAUST, 1893}

Parameira volgense Korotyaev, 1992: 816, syn. n.

\section{Taxonomic notes:}

This species occurs in southern Ural and from Altai to Transbaikalia, where it appears parthenogenetic. In addition, there is a bisexual form present along Volga River (around midlength), which Korotyaev (1992) described as P. volgense Kor. (compared with P. setosa Seidlitz, 1868 instead of $P$. gebleri). Due to the absence of morphological differences between type specimens of both species, we consider $P$. volgense conspecific to $P$. gebleri.

\section{Type material:}

P. volgense: Holotype, male (ZIN); Russia, Ul'yanovsk Prov., Radischevskiy Distr., Ashtala Mt., 9.viii.1991, A.Yu. Isaev leg. Paratypes: 2 ㅇ ㅇ (ZIN), labeled as holotype.

Other material examined:

Kazakhstan: 1 i (SZMN), Akmolinsk Prov., Shortandy, 24.vii-3.viii.1979, V. Mordkovitch leg.; 2 우 (SZMN), Akmolinsk Prov., Shortandy, 15.vi-5.viii.1978, V. Mordkovitch leg.

Mongolia: 2 우 (ZIN), Suhbaatar, Dzotol-Khan-Ula, 12.vii.1971, A. F. Yemelyanov leg.

Russia: 2 우 우 (SZMN), Krasnoyarsk Terr., Brazhnoye, v.1982; 2 우 (SZMN), Krasnoyarsk Terr., Vladimirovka, 19-22.07.1984, V. Mordkovitch leg. 2 우 (SZMN), Novosibirsk, Chistoozernyi Distr., Lake Karachi, 21.vi-13.vii.1970, V. Mordkovitch leg. 1 ㅇ (SZMN), Novosibirsk Prov., Toguchinskii Distr., Gornyi, Mt. Lysaya, 15.vii.1998, R. Dudko \& A. Legalov leg. 1 ㅇ (SZMN), Samara Prov., 13.5 km SSW

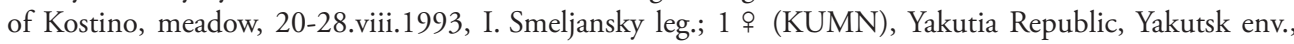
25.v.1980, Rentz leg. 


\subsection{Tribe Polydrusini Schoenherr, 1823}

According to traditional systematics Polydrusini comprises the genera with following superficial morphological characters:

1) antennal scrobes strictly lateral, with well developed edges;

2) pronotum without vibrissae at the sides of the anterior margin;

3) humeral prominences on elytra developed;

4) setal comb of hind tibiae, simple or with inner bare ridnge, additional comb always absent (Fig. 26);

5) setal comb of hind tibiae stricted by apical edge of tibia and not continuing on its dorsal edge;

6) claws connate.

Old and recent data have revealed many exceptions in character 3 within genera being considered in Polydrusini: Liophloeus Germar, 1817, Metadrosus Schilsky, 1910, Homapterus Fairmaire, 1857, Synaptorhinus Faust, 1889 (new placement), and Polydrusus subgenera Orodrusus Korotyaev et Meleshro, 1997, Scythodrusus Korotyaev et Meleshro, 1997, Leucodrusus, and Eudipnus when humeral processes are more or less reduced (SMreCzyŃski 1958; Borovec \& Fremuth 2000; original data of authors). That was expectable as aptery is already described in Phyllobiini and Cyphicerini (Korotyaev \& Egorov 1977; Morimoto et al. 2006).

Tribal relationships and phylogenetic pattern of Polydrusini genera are not studied yet. A hypothesis on the relationship of Polydrusini with Phyllobiini was proposed (ZHERIKHIN \& EgOROV 1991) because of similarity in general appearance, structure of thorax, limbs, and wing venation, but simultaneously significant differences were highlighted in structure of antennal socets, antennae, shape. Recently Japanese experts, supporting Zherikhins's opinion, descovered other defferences of Polydrusini from Phyllobiini: absence of denticles on medial edge of deciduous mandibular process (without denicles) and presence of styli on coxites of ovipositor (Мовімото et al. 2006). The statement on the presence of styli in all Polydrusini is not confirmed by our recent unpublished study of Polydrusus subgenera Scythodrusus and Orodrusus.

\section{Polydrusus Germar, 1817}

\section{Subgenus Eudipnus C. G. Thомson, 1859}

[type species: Curculio micans Fabricius, 1792 (= C. mollis StröM, 1768)]

Eudipnoidius Apfelbeck, 1898, syn. n.

[type species: Polydrosus sciaphiliformis APFelBeCK, 1898 by monotypy]

\section{Taxonomic notes:}

Apfelbeck (1898) erected the subgenus Eudipnoidius for Polydrusus sciaphiliformis solely on the basis that Eudipnoidius has weaker humeral processes on the elytra than Polydrusus, and he suggests Eudipnoidius to be placed in between the genera Sciaphobus (with reduced humeral processes correlated with lack of hind wings) and Polydrusus (with strongly developed humeral processes correlated with complete hind wings). All significant characters traditionally used for discriminating subgenera within Polydrusus (structure and shape of rostrum parts, position and shape of hypostomal-labial sutures and posterior tentorial pit, and also features of leg shape) are identical with Polydrusus (Eudipnus). We thus synonymise Eudipnoidius with Eudipnus. This is based on examination of one female syntype and one recently collected male of $P$. sciaphiliformis Aрғв. Both specimens are very similar to P. (Eudipnus) lateralis Gyll., P. (E.) cocciferae Kiesw. and $P$. (E.) mollis ( (Ттвӧм) in external morphology and genitalia structure of both sexes. P. sciaphili- 
formis differs from these species only in the shape of the scales of body vestiture and in the shape of the apex of the median lobe, while the internal sac armature and aggonoporium are almost identical.

\section{Type material:}

Polydrosus sciaphiliformis: Bulgaria: female, syntype (MTMB), 'Sofia, Vitosa pl.'.

Other material examined:

Polydrosus sciaphiliformis: Greece: 1 ơ (MTMB), 'Greece, Trakia, Megalo Dereio, 25.v.2004, S. Ilniczky leg.' I'Polydrosus sciaphiliformis Apfelbeck, 1898 Yunakov det. 2009'.

Polydrosus lateralis: Greece: $20^{\top} 0^{\star}, 2$ ㅇ (ZIN) 'Thrakia'; $10^{\star}, 1$ ㅇ (ZIN) 'Attica'.

\section{Subgenus Eustolus C. G. Thомson, 1859}

[type species: Curculio flavipes DeGeER, 1775]

Tylodrusinus ReitTer, 1916: 56, syn. n.

[type species: Polydrusus julianus ReItTer, 1916]

\section{Taxonomic notes:}

Reitter (1916) erected the subgenus Tylodrusinus for the single species Polydrusus julianus from the Xinjiang province of China (Figs 3, 4). In general appearence its holotype differs from species of the subgenus Eustolus basically by the vestigial rather than extensive condition of shining metallic scales on the body. E. Reitter stressed this difference in the original description but did not provide any other significant evidence for the discrimination of Tylodrusinus. The structure of the head, pronotum, elytra, legs and abdomen agrees with that in Eustolus. There are no other particular characters suggesting Tylodrusinus to be classified as a distinct subgenus. Therefore P. julianus RTt. is here transferred to the subgenus Eustolus C. G. Thomson, 1859. In a discussion of this topic Dr. B. A. Korotyaev has agreed upon this synonymy.

Lectotype designation is required and here done because the original description was based on several specimens.

\section{Type material:}

Polydrusus julianus: Lectotype, female here designated (MTMB): 'Turkestan [printed]' / 'Kuldscha [printed]' / 'Kuldscha [hand written]' / 'julianus m. Fn. Grm V. [hand written]' / 'Coll. Reitter [printed]' / 'Holotypus Polydrusus julianus Reitter, 1916 [standard museum label in red frame]' / 'Lectotype Polydrusus julianus Reitter, Yunakov des., 2009 [red, printed]'.

\section{Subgenus Metallites Germar, 1824: 455}

\section{Polydrusus impar GozIs, 1882}

vranicensis ReITter, 1905: 247, syn. $\mathbf{n}$.

\section{Taxonomic notes:}

According to ICZN (article 45.6.4), Polydrusus impar var. vranicensis has to be treated as subspecies. The type locality is in Bosnian highlands, where this form occurs in the subalpine zone. The specimens differ from the common appearance of $P$. impar only in the absence of scales 
with metallic shine in the body vestiture, as also mentioned by E. Reitter in the original description. A reduction of scales with metallic shine in the vestiture is very common among Entiminae groups in which the vestiture usually contains such scales. For example, complete reduction of such scales can be observed in some specimens of Polydrusus amoenus Germar, 1824, Phyllobius pomaceus Gyllenhal, 1834, and Ph. glaucus (Scopoli, 1763). There are no other morphological reasons to discriminate $P$. impar vranicensis from typical specimens of $P$. impar, which occur in Vranice Planina, too.

\section{Type material:}

Syntypes, 2 females (MTMB), 'Bosnia, Vranice Pl.' / 'leg. Leonhard'/ 'Metallites impar v. vranicensis $\mathrm{m}$. [Reitter's hand writing]'.

\section{Subgenus Eurodrusus Korotyaev et Meleshio, 1997}

[type species: Polydrusus confluens Stephens, 1831, by original designation]

\section{Polydrusus cervinus (Linnaeus, 1758)}

\section{Taxonomic notes:}

Polydrusus cervinus is a highly variable species with a huge distribution range over the whole of Europe. Members of this species were described for many times. Here the type series of $P$. iris, already proposed to be a synonym of $P$. cervinus (DALla TORRE et al., 1936), is critically examined. It consists of three syntypes obviously belonging to two different species, Polydrusus cervinus and Pachyrhinus mustela (Herbst, 1797). This situation requires a lectotype designation of Curculio iris for the sake of stability of nomenclature.

\section{Type material:}

Lectotype, male, here designated (ZMUC): 'iris', 'Lectotypus Curculio iris Fabricius Yunakov des. 2010', 'Polydrusus cervinus (L.) Yunakov det.'. Paralectotypes: 1 + (ZMUC), 'iris', 'Paralectotypes Curculio iris Fabricius Yunakov des. 2010', 'Polydrusus cervinus (L.) Yunakov det.'; 1 + (ZMUC), 'iris', 'Paralectotypes Curculio iris Fabricius Yunakov des. 2010', 'Pachyrhinus mustela (Hbst.) Yunakov det.'.

\section{Synaptorbinus FAUST, 1889 (new placement)}

[type species: Synaptorhinus simplex FAUST, 1889, by monotypy]

This poorly-known monotypic genus was erected for S. simplex FAUsT, 1889 from Turkey. The original description in FAUST (1889) is fairly incomplete, and we thus provide a redescription that includes the morphological details required for comparison with resembling Entiminae genera.

\section{Redescription:}

Measurements. Body length $4 \mathrm{~mm}$, width $2.2 \mathrm{~mm}$. Vestiture and coloration. Head and body densely covered with round, gold-cupreous scales with slightly pronounced pearl shine. Frontoepistome covered with scattered scales (Figs 14, 15). Antennal scape sparsely covered with 
slender recumbent and suberect scales; funicle without recumbent scales. Intervals between elytral striae weakly convex, covered with spatulate suberect scales. Light scales form an indistinct pattern of small blurs on the elytra.

\section{Head (Figs 16-18, 23)}

Compound eyes small, strongly and irregularly convex, their maximum width situated posteriad of their midlength. Epifrons distinctly narrowed apically, flat. Epistome and frons fused into a frontoepistome; this is coarsely punctate. Epistome with a pair of setae. Frons with weakly developed setal row. Frontoepistome demarcated from epifrons by scattered scales; U-shaped sharp carina not developed. Anterior margin of clypeus bare, without comb of microscopic setae. Ventral side of head (Fig. 24): Prementum broad, rounded, entirely covering buccal cavity, with one pair of setae. Labial palps entirely hidden. Postgenae strongly protruding. Hypostomolabial sutures completely separated and reduced to small pits. Antennae: Robust. Scape evenly but weakly S-shaped and widened apically, $1^{\text {st }}$ funicular segment $1.5 \mathrm{x}$ as long as $2^{\text {nd }}$; rest of segments weakly rounded, slightly oblong to as long as wide; club ovate, compact, with fused segments, distinctly bordered from funicle.

\section{Thorax:}

Pronotum transverse $(\mathrm{PL} / \mathrm{PW}=0.85)$, strongly rounded at the sides, widest in posterior half; at posterior margin $1.34 \mathrm{x}$ as wide as at anterior margin; its disk weakly and evenly convex longitudinally and transversely (Fig. 21). Legs: Femora obtuse, moderately swollen in middle part. Hind tibiae with simple corbels (Fig. 26). Fore tibiae widened externally (Fig. 19). Fore and middle tibiae slightly mucronate. Hind tibiae with mucro vestigial (Fig. 28). Tibial spurs absent.

\section{Abdomen:}

Anal ventrite sharply triangular, its apical edge narrowly rounded, sternite 8 with plate triangular and densely setose (Fig. 25). Tergite 6 sharply sinuate at the apex (Fig. 30).

\section{Genital structures (Figs 29, 31-33)}

Ovipositor flattened; coxite divided in two sclerites; well developed stick-shaped styli. In spermatheca, ramus and collum very small. Spiculum ventrale with lamella rounded and heavily sclerotized, its anterior margin densely setose; apodeme thick with small caput developed.

\section{Diagnosis and implications on systematic position:}

Synaptorhinus was commonly attributed to (or associated with members of) Brachyderini (DALLA Torre et al. 1936) or Sciaphilini (Alonso-Zarazaga \& Lyal 1999) but either placement may be inadequate as it lacks the typical autapomorphies most of Sciaphilini genera (epistome demarcated from frons by a sharp V-shaped ridge, frontoepistome convex or demarcated from epifrons by U- or V-shaped ridge; except of Euidosomus ReITTER, 1904) and Brachyderini (anterior margin of clypeus with a comb of microscopic setae).

Synaptorhinus also resembles the Cneorhinini genera Attactagenus Tournier, 1876, Philopedon Schoenherr, 1826, and particularly Sericopholus Desbrochers, 1893 in general appearance and the triangular shape of the anal ventrite. However, Synaptorhinus lacks the significant autapomorphies of Cneorhinini, which are the presence of an additional setal comb on the hind tibiae (the corbel) and a transversal sulcus separating the epifrons from the remaining head capsule.

On the other hand, Synaptorhinus has strongly protruding postgenae, which likely is an autapomorphy of the Polydrusus subgenus Eudipnus in Polydrusini. Synaptorhinus is particularly similar to $P$. (E.) lucianae Francia, 1985 in the shape of the head and eyes. On this basis we tentatively 
place Synaptorhinus Fst. in the tribe Polydrusini, near Eudipnus. It differs from all Eudipnus species by the lack of a frontal fovea and complex of reductions due to the aptery sindrome: reduction of scutellum and humeral processes of elytra.

Type material:

Turkey: Lectotype, female, here designated (MTD), with labels: gold board; 'Asia minor, Pipitz' 'Lectotypus Synaptorhinus simplex Faust, Yunakov des., 2009'. Paralectotype, female (MTD) with the same labels as in lectotype; 'Paralectotypus Synaptorhinus simplex Faust, Yunakov des., 2009'.

\section{Chiloneus SCHOENHERR, 1842: 234}

[type species: Chiloneus siculus BoHeman, 1842, by original designation]

Chilonorrhinus ReITter, 1915: 187, syn. n.

[type species: Chilonorrhinus sitonoides ReITTER, 1915, here designated]

\section{Taxonomic notes:}

Chiloneus includes 46 species distributed over the Mediterranean region. Chilonorrhinus includes 4 species from Algeria, Italy, Greece, and Israel. ReItTER (1915b) established Chilonorrhinus only based on the shape of scales (piliform, vs broad in Chiloneus). Head shape, the proportions of the body, and the structure of the frontoepistome are very similar in Chilonorrhinus and Chiloneus. Our examinations suggest that the type species Chilonorrhinus sitonoides differs from Chiloneus species only by having piliform hairs in its vestiture and a fine punctuation of the pronotum (Fig. 9). Difference of this kind are not significant enough to separate species at genus level. The female genitalia are very similar in Chilonorrhinus sitonoides and most Chiloneus species. We consider this sufficient reason to transfer Chilonorrhinus sitonoides to Chiloneus. The other three Chilonorrhinus species (which we did not examine) are also transferred to Chiloneus, as there is no evidence in favour of their separation from Chilonorrhinus sitonoides at genus level. The following new combinations are thus proposed: Chiloneus sitonoides (ReITTER, 1915), comb. n., Chiloneus aliquoi (Pesarini, 1974), comb. n., Chiloneus corcyreus (Penecke, 1935), comb. n., and Chiloneus sahlbergi (ReITter, 1915), comb. n.

\section{Type material:}

C. sitonoides (Figs 9-13): Holotype, female (MTMB): 'Algier, Reitter (Leder) [printed] / X.p.g. Sciaphilus' [hand written] / Desbrochersella sitonoides $\mathrm{m}$ in lit. [hand written by E. Reitter] / Chilonorrhinus sitonoides m. Type, 1915 [hand written by E. Reitter] / coll. Reitter [printed] / Monotypus Chilonorrhinus sitonoides Reitter, 1915' [hand written label with red frame].

\section{Wittmerella PESARINI, 1973: 81}

[type species: Wittmerella viridisetosa PeSARINI, 1973; by original designation]

Sciaphilomorphus Alonso-Zarazaga \& Lyal, 1999: 177, syn. n.

[type species: Sciaphilus aurosus BoHEMAN, 1845; by original designation]

Wittmerella viridisetosa is the only species assigned to this genus, and males are unknown. The original description in PESARINI (1973) is overall sufficient, but there are some gaps to be filled. 


\section{Partial redescription:}

Measurements. Body length 3.65-4.80 mm, width 1.55-1.75 mm. Female genitalia. Sternite VIII with very transverse lamella and long, thin apodeme. Caput of apodeme vestigial. Ovipositor with coxite undivided, poorly setose, without styli (Fig. 56). Spermatheca robust, ramus and collum situated very close to one another, vestigial (can be recognized by junction of spermathecal gland duct and ductus spermaticus, respectively); corpus not swollen. (Figs 44-45).

\section{Diagnosis:}

The structure and shape of the antennae and rostrum in Wittmerella (including Sciaphilomorphus) are very similar to those of Polydrusus subgenus Leucodrusus STIERLin, 1884 and Sauromates arnoldii KoROTYAEV, 1992, which suggests these groups to be related to each other (Figs 34, 37).

\section{Taxonomic notes:}

Sciaphilomorphus includes two small species (body length 3-4 mm) occurring in Italy, Tunisia and Algeria: S. aurosus (BoH.) and S. sulcirostris (CHEvr.). Both are wingless, and the pterothorax is strongly modified as a consequence of this (as convergently in many Entiminae). The aedeagus of Sciaphilomorphus sulcirostris and S. aurosus has dentate ligulae (Fig. 49). The internal sac has a densely spiculate field in its apical half, and the aggonoporium is almost unarmed. The tegmen is heavily sclerotized, the tegminal plate with the parameres is well developed (Fig. 50). The furcal arms of male sternite IX are heavily sclerotized (Fig. 51). Tergite VIII has a deep apical groove (Fig. 52).

The previous proposal of identity of Sciaphilomorphus with Stasiodis GozIs, 1886 (YunAKov 2006) seems to be inappropriate, misled by the extreme similarity in general appearance due to body miniaturization. Stasiodis is distinct from Sciaphilomorphus by its tenuous antennal scape and slender funicular segments, ligulae of median lobe membranous, aggonoporium with well developed armature, parameres fused in proximal half, male tergite VIII without transverse groove (Figs 52-55), ramus and collum of spermatheca situated far apart, coxites of ovipositor with well developed styli, and sternite VIII with large lamella (Figs 46-47, 57).

Sciaphilomorphus and Wittmerella viridisetosa (Figs 5-8 in PEsARINI 1973) are also very similar in general appearance, but also in most morphological details. They share a similar structure of the epistomal area: epistome fused with frons, glabrous, bearing well visible pores, with few pairs of chaetae. The morphology of the female postabdomen is also very similar: sternite VIII with large small, transverse lamella; ramus and collum of spermatheca situated very close to one another. Wittmerella differs from both Sciaphilomorphus species by the vestigial condition of the lateral edges of the rostrum posteriad of the antennal articulation (Fig. 35), by the elongate body shape, and by the pterothorax being less modified along the winglessness syndrome. We consider this insufficient to justify the separation of two genera, Wittmerella and Sciaphilomorphus.

On this basis we consider Sciaphilomorphus congeneric with Wittmerella, and the following new combinations are proposed here: Wittmerella aurosa (BoHEMAN, 1845), comb. n., W. sulcirostris (Chevrolat, 1860), comb. n.

\section{Type material:}

W. viridisetosa: Iran: Holotype, female (NMB) (L: $4.8 \mathrm{~mm}$; W: $1.75 \mathrm{~mm}$ ) 'Polour-Abali 17.5. / 2100/2600m', 'Iran 1970 / Wittmer, v. Bothmer', 'Wittmerella viridisetosa m. Holotypus'; Paratype, female (NMB) (L: $4.2 \mathrm{~mm}$, W: $1.7 \mathrm{~mm}$ ): labeled as holotype. 
Other material examined:

W. viridisetosa: Turkey: 3 females (MTMB 2, ZIN 1): 'Turkey, Prov. Siirt, Kusgunkiran G̦eçidi, 1.vi.1989, leg. A. Podlussány'; 1 female (ZIN): 'Turkey, TR06-34, Muş, Hwy 959, Otluk Dağları, 41.7 km ENE of Muş, 3852'13.0" 415' 33.8" 1740 13.vi.2006, A. Konstantinov leg.'.

\section{Acknowledgements}

We sincerely thank Drs O. Merkl (MTMB) and A. Solodovnikov (ZMUC) for the opportunity to examine type specimens meaningful to this contribution, B. A. Korotyaev (ZIN), A. N. Drogvalenko (KUMN) and A. A. Legalov (SZMN) for supplying material. We also thank to Dr. Roman Borovec for valuable comments to this work. The investigation has been supported by the Deutsche Forschungsgemeinschaft (DFG; grant KL 1162/4-1).

\section{References}

Alonso-Zarazaga, M. A. \& Lyal, CH. H. C. 1999: A World catalogue of families and genera of Curculionoidea (Insecta: Coleoptera) (excepting Scolytidae and Platypodidae). - Barcelona: Entomopraxis, $315 \mathrm{p}$.

Arzanov, Yu. G. 2003: Use of the endophallus characters in the systematics of the rhynchophorous beetles (Coleoptera, Curculionoidea). - Entomological Review 83 (8): 930-944.

Apfelbeck, V. 1898: Contribution to Palaearctic Curculionidae. Synonymy and geographical data and descriptions of new species in the Balkan peninsula. - Glasnik zemaljskog muzeja Bosni i Hercehovini, Sarajevo 10: 265-313 [in Croatian].

Borovec, R. \& Fremuth, J. 2000: On the taxonomic status of the genus Chaerodrosus Reitter, 1916 (Insecta: Coleoptera: Curculionidae: Brachyderinae). - Reichenbachia 33 (52): 399-406.

Dalla Torre, K. W.; Emden van M. \& Emden van, F. 1936: Curculionidae: Brachyderinae I. - In: Schenkling, S. (ed.), Coleopterorum Catalogus. W. Junk, Pars 147. Berlin, 1-132.

FÅHraeus, O. I. 1871: Coleoptera Caffrariae, annis 1838-1845 a J. A. Wahlberg collecta. Curculionides descriptsit. - Öfversigt af Kongliga Vetenskaps-Akademiens Förhandlingar 28 (1): 3-69.

Korotyaev, K. 1992: New and little known species of weevils (Coleoptera: Curculionidae) from Russia and neighbouring countries. - Entomologicheskoe Obozrenie 71 (4): 807-832 [in Russian].

Korotyaev, B. A. \& Egorov, A. B. 1977: A review of the weevil genus Phyllobius Germ. (Coleoptera, Curculionidae) of East Siberia, Far East of USSR and Mongolia with notes on species from other regions. - Nasekomye Mongolii 5: 379-449 [in Russian].

Korotyaev, B. A. \& Meleshro, J. Ye. 1997: On the systematics of the weevil genus Polydrusus (Coleoptera: Curculionidae). - Zoosystematica Rossica 6: 275-286.

Magnano, L. 2003: Una nuova specie di Parameira di Turchia. XLII. Contributo alla conoscenza dei Curculionidi. - Bollettino della Societa entomologica italiana 134: 245-252.

Marshall, G. A. K. 1942: On some East African Otiorrhynchinae (Coleoptera, Curculionidae). - Annals and Magazine of Natural History 9 (11): 1-26.

Marshall, G. A. K. 1943: On the multistriate Embrithini (Coleoptera, Curculionidae). - Annals and Magazine of Natural History 10 (11): 607-616.

Morimoto, K.; Kojima, H. \& Miyakawa, S. 2006: The Insects of Japan. Vol. 3. Curculionoidea: general introduction and Curculionidae: Entiminae (part 1). Phyllobiini, Polydrusini and Cyphicerini (Coleoptera). - Fukuoka: Touka Shobo Co. Ltd., i-iv, 1-406.

Oberprieler, R. G. 1988: Revision of the Tanyrhynchini of continental Africa (Coleoptera, Curculionidae) I. Introduction and review of the genera, revision of the genus Brachytrachelus SCHÖNHERR and description of Afroleptops gen. nov. - Entomology Memoir, Department of Agriculture and Water Supply Republic of South Africa 71: 1-50. 
Pesarini, C. 1973: Nuovi specie di Curculionidi raccolte in Turchia ed in Persia dal Dott. W. Wittmer e descrizione de un nuovo genere. - Bolletino della Societa Entomologica Italiana 105 (4-6): 80-85.

Reitter, E. 1905: Sechzehn neue Coleopteren aus der palaearktischen Fauna. - Wiener Entomologische Zeitung 24: 241-251.

Reitter, E. 1912: Übersicht der Untergattungen und Artengruppen der Gattung Otiorhynchus Germ. Wiener Entomologische Zeitung 31: 45-67.

Reitter, E. 1915a: Zwei neue Coleopteren-Gattungen der Curculionidae. - Entomologische Blätter 11 (4-6): 115-118.

ReitTer, E. 1915b: Übersicht der mir bekannten Arten der Rüsselkäfergattungen Chiloneus SchöNH. und Chilonorrhinus ReitT. - Wiener Entomologische Zeitung 34: 187-191.

Reitter, E. 1916: Fauna Germanica. Die Käfer des Deutschen Reiches. Nach der analytischen Methode bearbeitet. Vol. 5. - K.G. Lutz. Verlag, Stuttgart. 343 pp., 4 plates on pp. 153-168.

Schoenherr, C. J. 1843: Genera et species Curculionidum, cum synonymia hujus familiae. Species nova ant hactenus minus cognitae, descriptionibus a Dom Leonardo Gyllenhal, C. H. Boheman, et entomologis aliis illustratae. - Paris: Roret, 7 (1): 461 pp.

SmreCZyŃski, S. 1958: Vorstudien zu einer Monographie des Subgenus Liophloeodes Liophloeus Germar, 1824) (Coleoptera, Curculionidae). - 3 (3): 67-120.

Thompson, R. T. 1992: Observations on the morphology and classification of weevils (Coleoptera, Curculionoidea) with a key to major groups. - Journal of Natural History 26: 835-891.

WANAT, M. 2007: Alignment and homology of male terminalia in Curculionoidea and other Coleoptera. Invertebrate Systematics 21: 147-171.

Yunakov, N. N. 2004: On the taxonomy of the weevil genus Parameira Seidl. (Coleoptera, Curculionidae: Entiminae). - Zoologitshesky Zhurnal 83 (10): 1284-1289.

Yunakov, N. N. 2006: New synonyms in the Entiminae. - Zoosystematica Rossica 14 (2) (2005): 263-265.

Yunakov, N. N. \& Korotyaev, B. A. 2008: On the systematics of the weevil genus Araxia Khnzorian with descriptions of new taxa from Transcaucasia, Turkey, and Turkmenistan (Coleoptera: Curculionidae: Entiminae). - Insect Systematics \& Evolution 39: 39-54.

Zherikhin, V. V. \& Egorov, A. B. 1991: Weevils (Coleoptera, Curculionidae) of the U.S.S.R. Far East (a Review of the Subfamilies with Description of New Taxa). - Vladivostok: Institute of Biology and Soil science. 164 pp. [in Russian].

\section{Author's addresses:}

Dr. Nikolai N. Yunakov

Natural History Museum

University of Oslo

P. O. Box 1172

Blindern NO-0318

Oslo, Norway

E-mail: n.yunakov@gmail.com
Subject editor:

Dr. Klaus-Dieter Klass

Senckenberg Natural History Collections Dresden

Museum of Zoology

Königsbrücker Landstraße 159

01109 Dresden

Germany

E-mail:klaus.klass@senckenberg.de
R. Borovec 

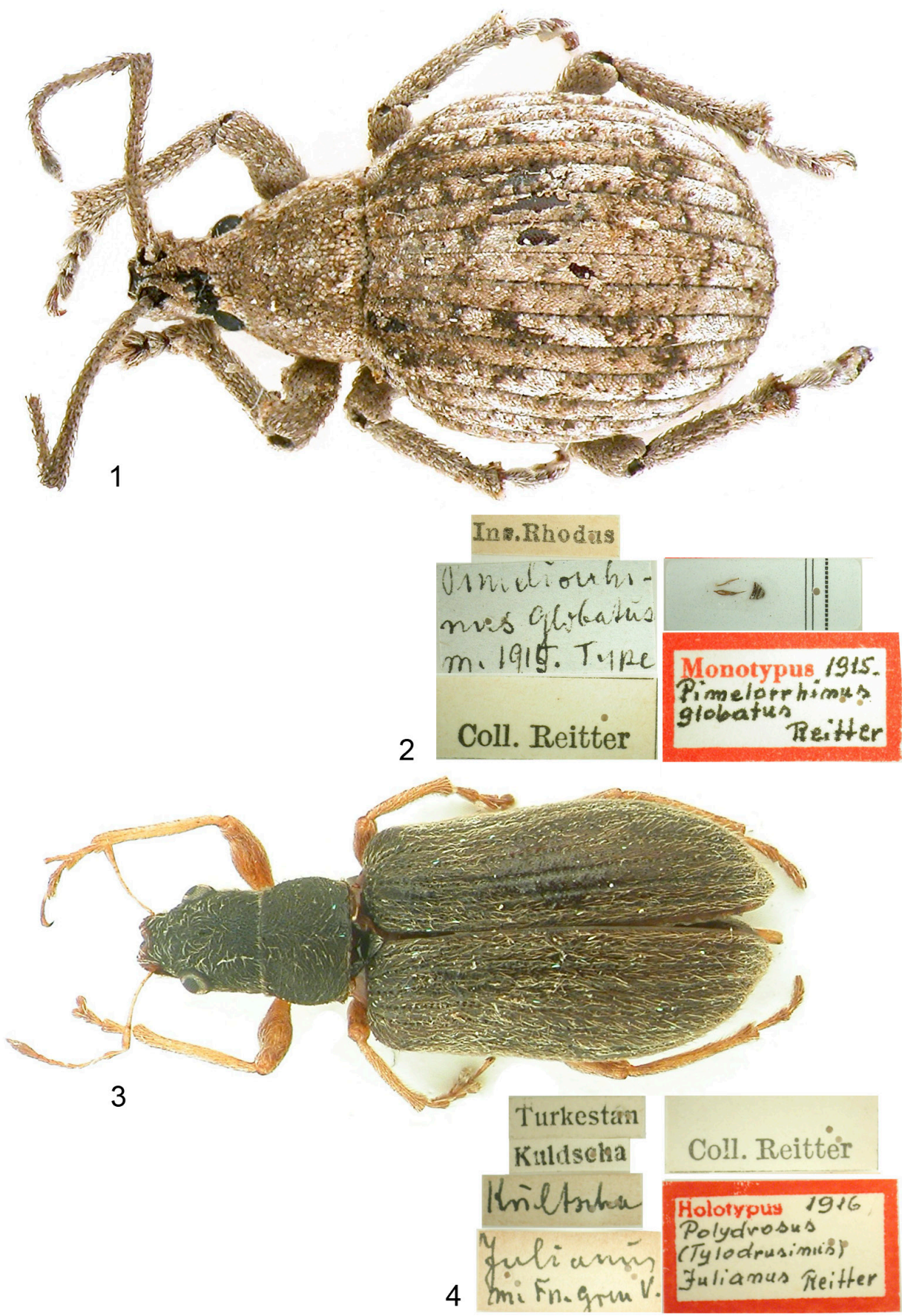

Figs 1-4: Pimelorrhinus and Polydrusus, general view. Pimelorrhinus globatus ReItTer, 1915 (= Ellimenistes setulosus FÅHraeus, 1871), holotype male. 1: dorsal view; 2: original labels and glueboard with dissected aedeagus and 9th sternite. Polydrusus julianus Reitter, 1916, holotype female. 3: dorsal view; 4: original labels. 

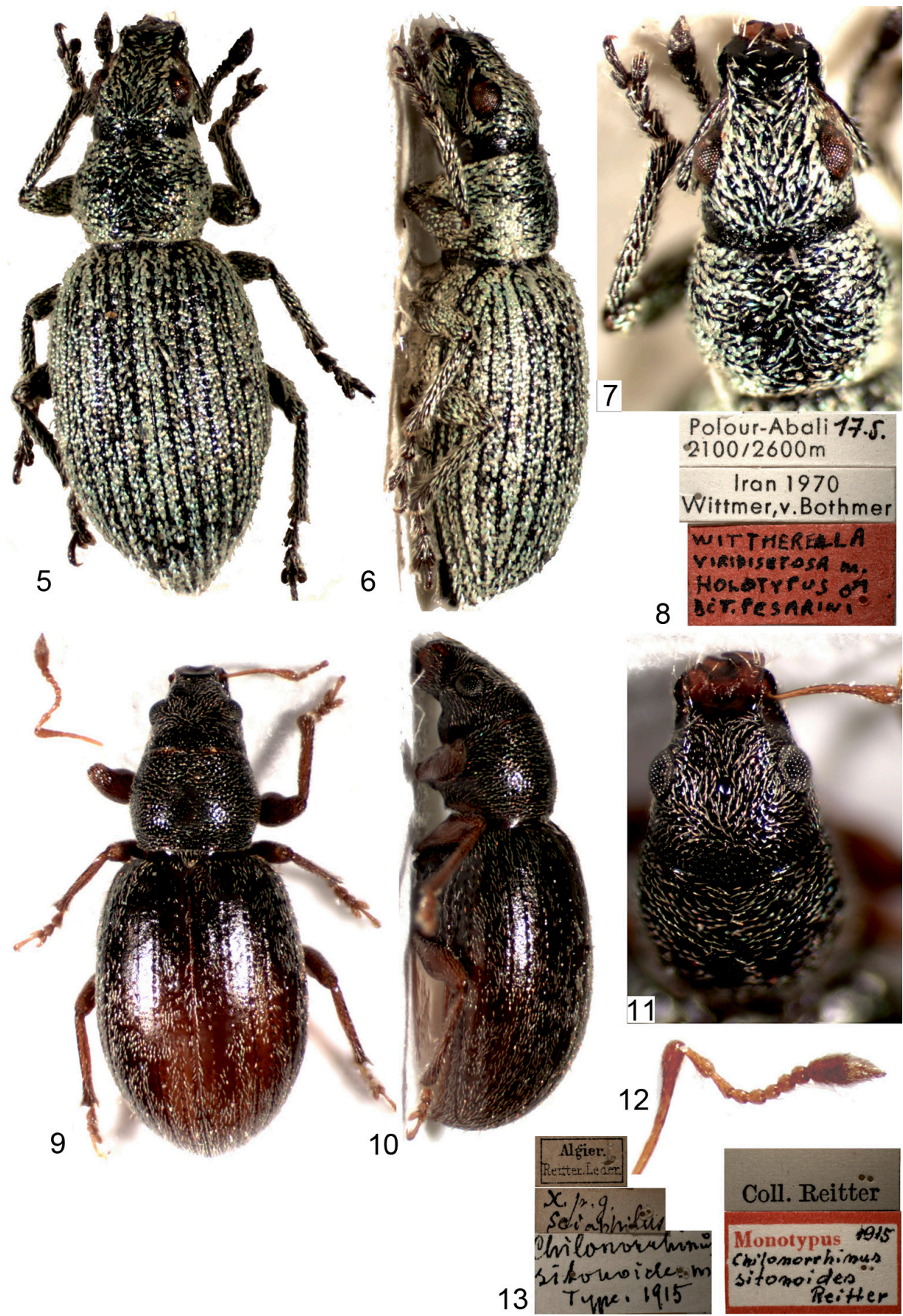

Figs 5-13: Wittmerella and Chilonorrhinus. Wittmerella viridisetosa PesArini, 1973, holotype male. 5: dorsal view; 6: lateral view; 7: head and pronotum, dorsal view; 8: original labels. Chilonorrhinus sitonoides Reitter, 1915, holotype female. 9: dorsal view; 10: lateral view; 11: head and pronotum, dorsal view; 12: antenna; 13: original labels. 

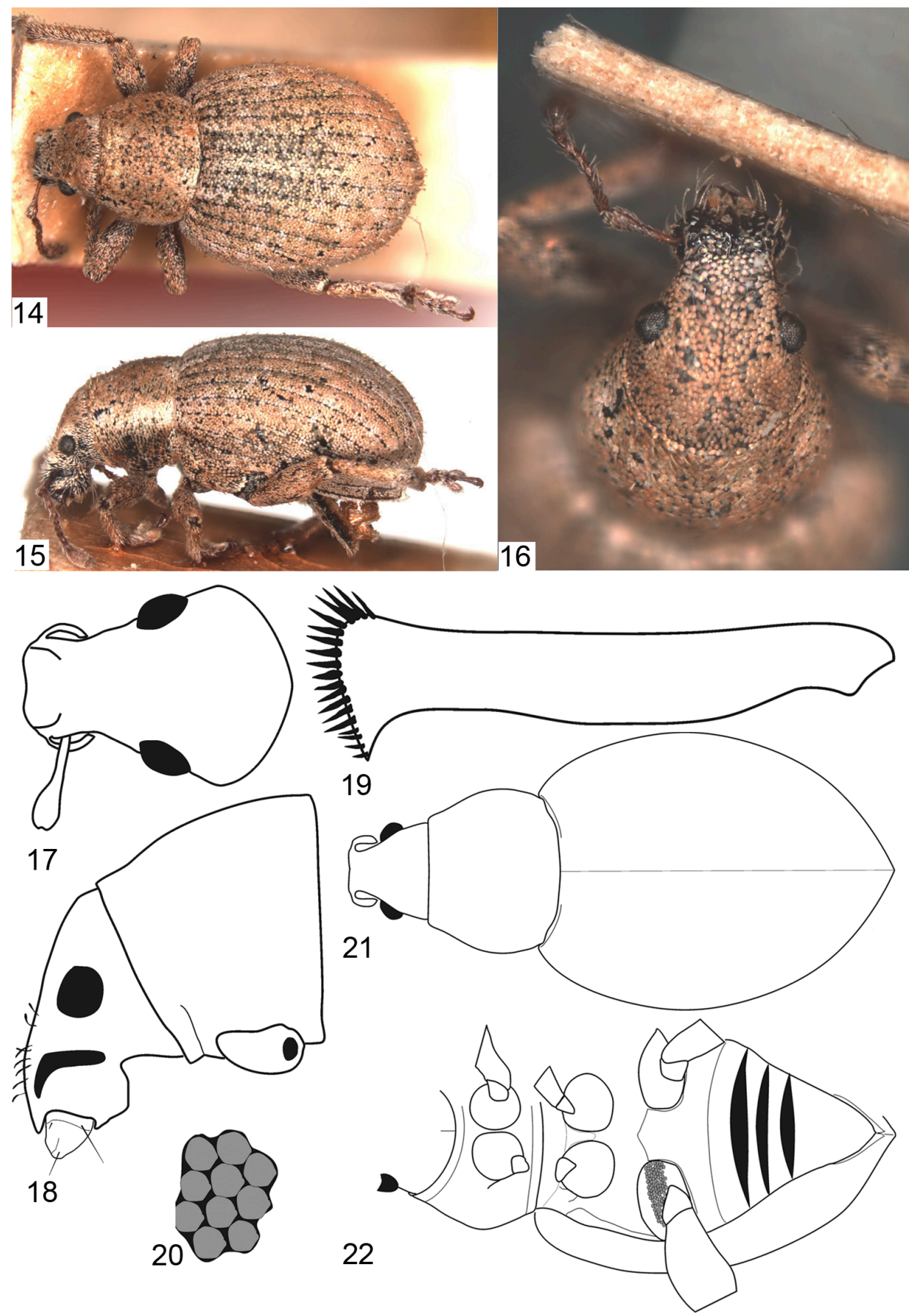

Figs 14-22: Synaptorhinus simplex FAUsT, 1889, syntype, female. 14: dorsal view; 15: lateral view; 16: head, dorsal view; 17: head outline, dorsal view; 18: head and prothorax outline, lateral view; 19: right protibia, anterior view; 20: scaling of body, schematic; 21 : body outline, dorsal view; 22: idem, ventral view, with scaling indicated on left metacoxa. 


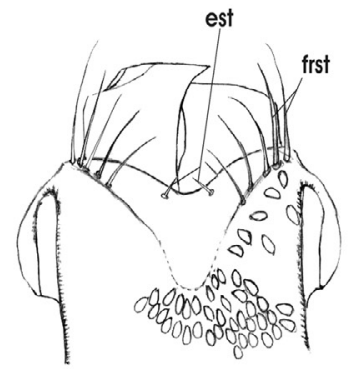

23
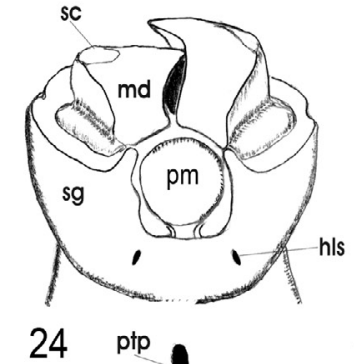

ptp
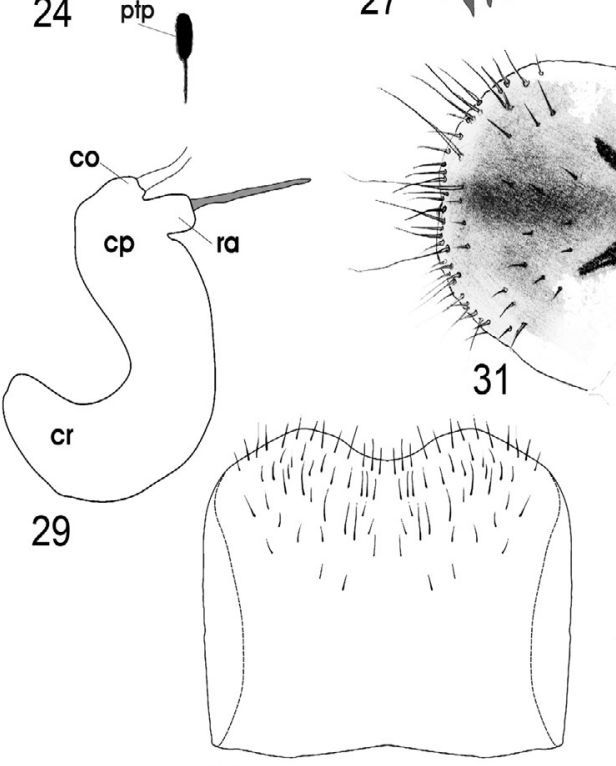

30

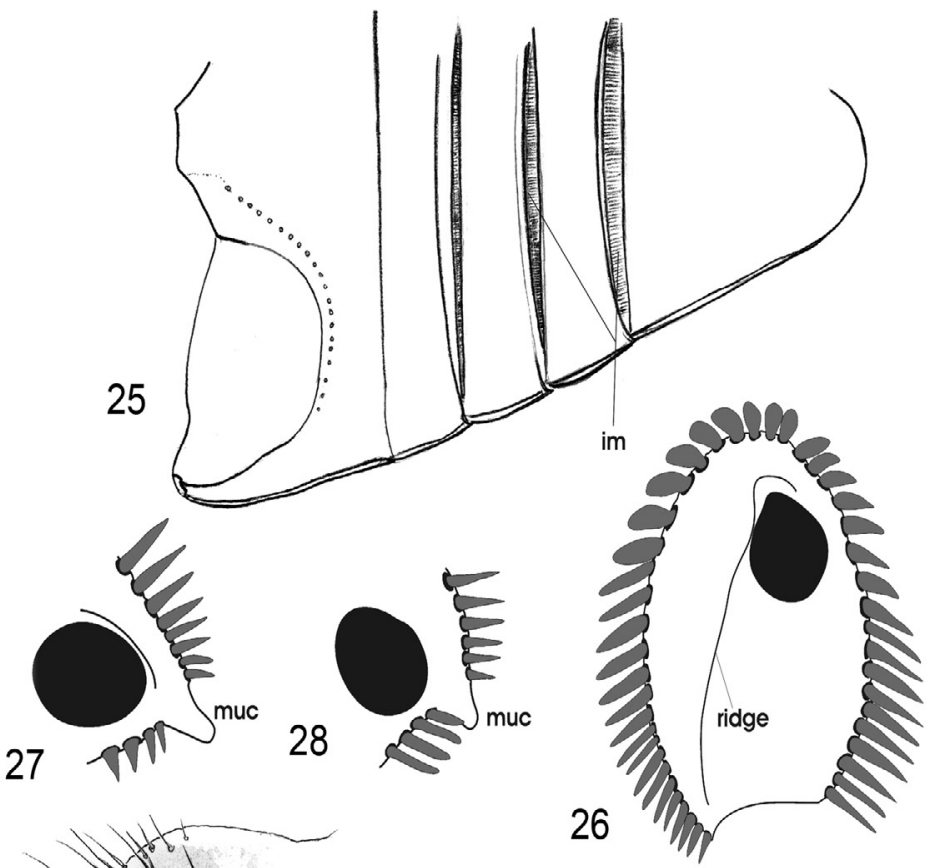

1
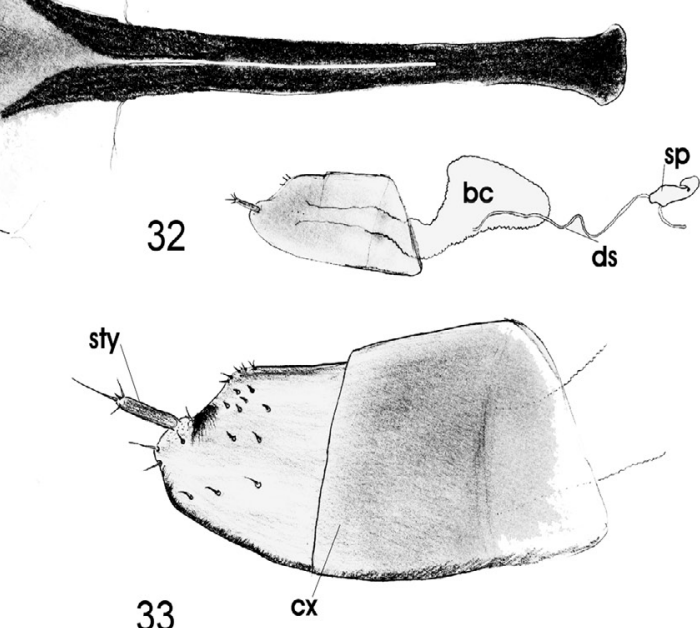

33

Figs 23-33: Synaptorhinus simplex FAUsT, 1889, syntype, female. 23: epistomal area of rostrum, dorsal view; 24: rostrum, ventral view showing buccal cavity; 25: visible abdominal sternites (ventrites), ventral view showing intersternal membranes; 26: right hind tibia apical surface, view from distally, ventral (= internal) side to the right, showing ridge; 27 : internal apical angle of right fore tibia, internal view from distally; 28 : idem, right middle tibia; 29: spermatheca; 30: abdominal tergite VI, dorsal view; 31: sternite VIII (spiculum ventrale); 32: ovipositor with bursa copulatrix and spermatheca, left-lateral view; 33: left coxite and stylus of ovipositor, magnified. Abbreviations: bc - bursa copulatrix, co - collum, cp - corpus, cr - cornu, cx - coxite, dc - ductus spermaticus, est - epistomal setae, frst - frontal setae, hls - hypostomolabial suture, im - intersternal membrane, md - mandible, muc - mucro, pm - prementum, ptp - posterior tentorial pit, ra - ramus, sc - mandibular scar, sg - subgena, sty -stylus. 

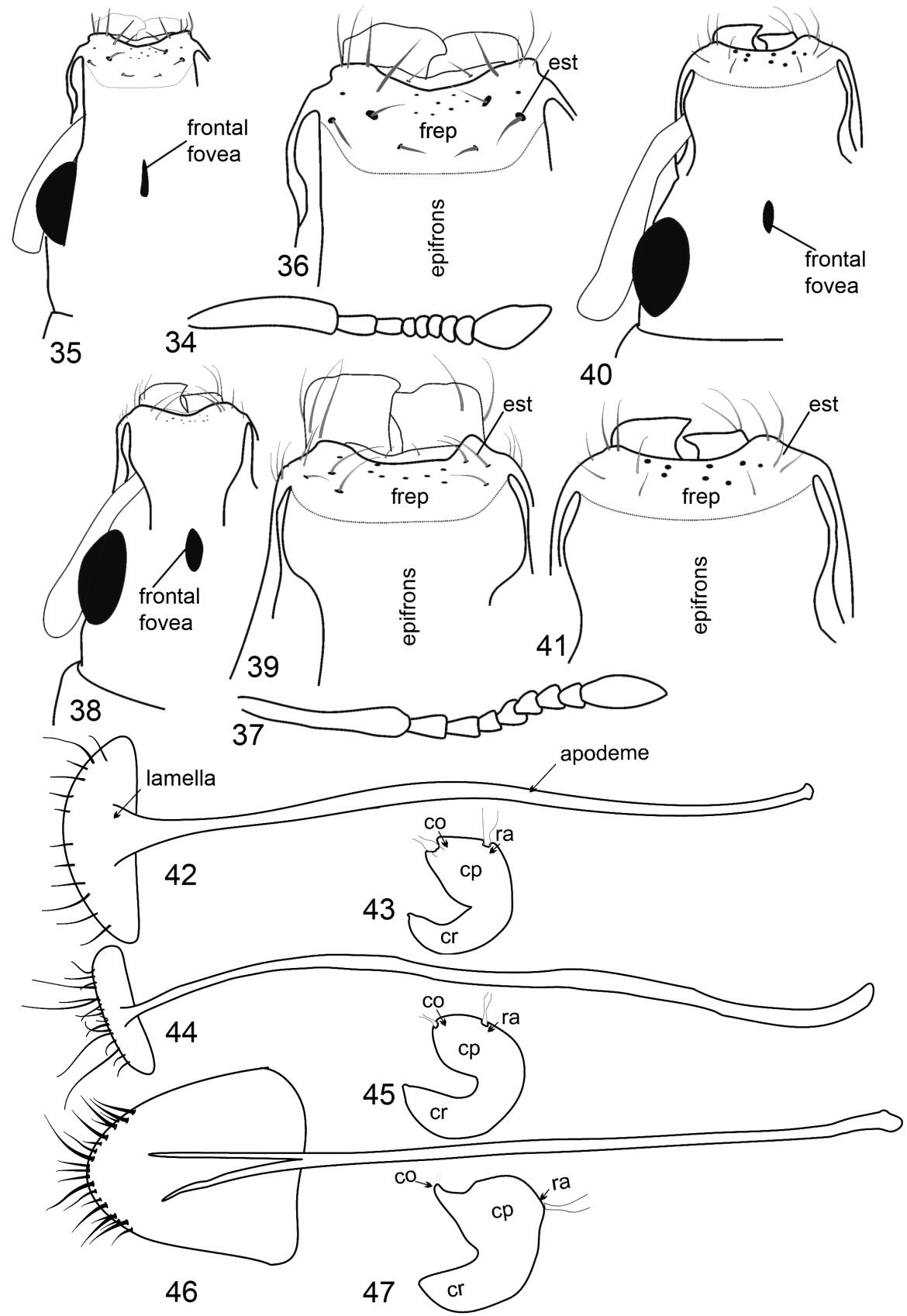

Figs 34-47: Wittmerella, Sciaphilomorphus and Sauromates; head details and female genitalia. Wittmerella viridisetosa Pes.: 34: antenna, 35: head, 36: apex of rostrum; Sciaphilomorphus aurosus (BоH.): 37: antenna, 38: head, 39: apex of rostrum; Sauromates arnoldii Kor.: 40: head, 41: apex of rostrum. Sciaphilomorphus sulcirostris (Chevr.) 42: sternite VIII, 43: spermateca. Wittmerella viridisetosa Pes.: 44: sternite VIII, 45: spermateca. Stasiodis parvulus (F.): 46: sternite VIII, 47: spermateca. Abbreviations: co - collum, $\mathrm{cp}$ - corpus, $\mathrm{cr}$ - cornus, ra - ramus, frep - frontoepistome. 

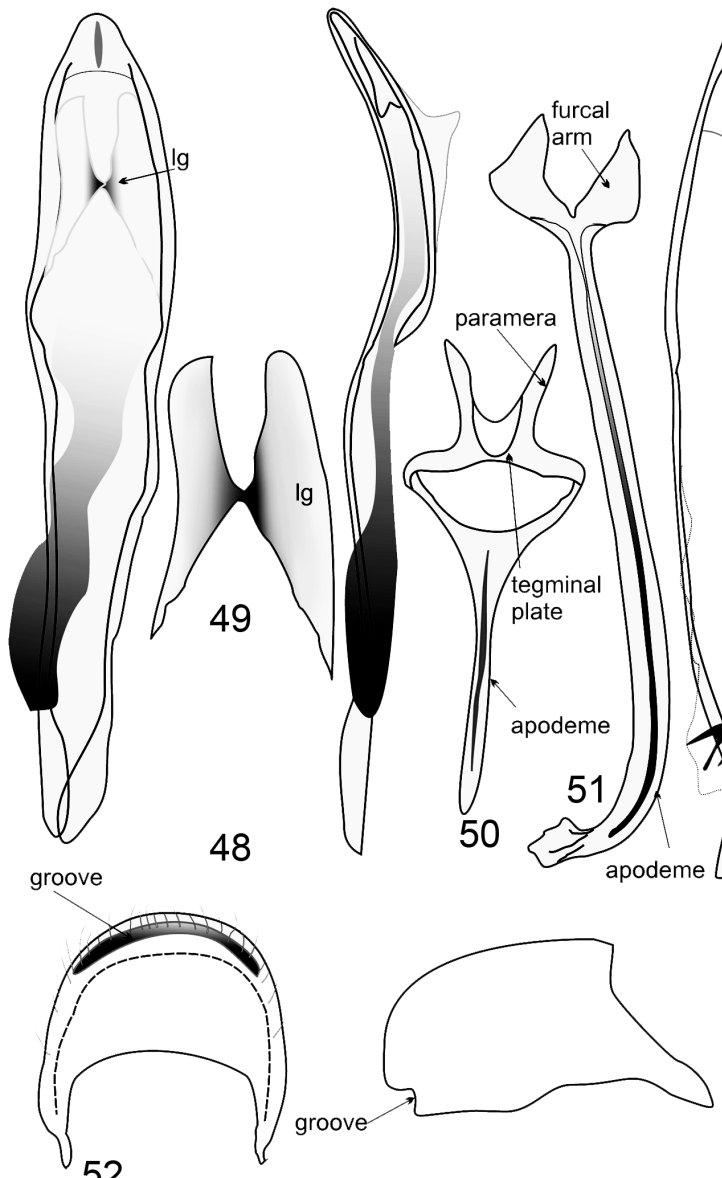

52
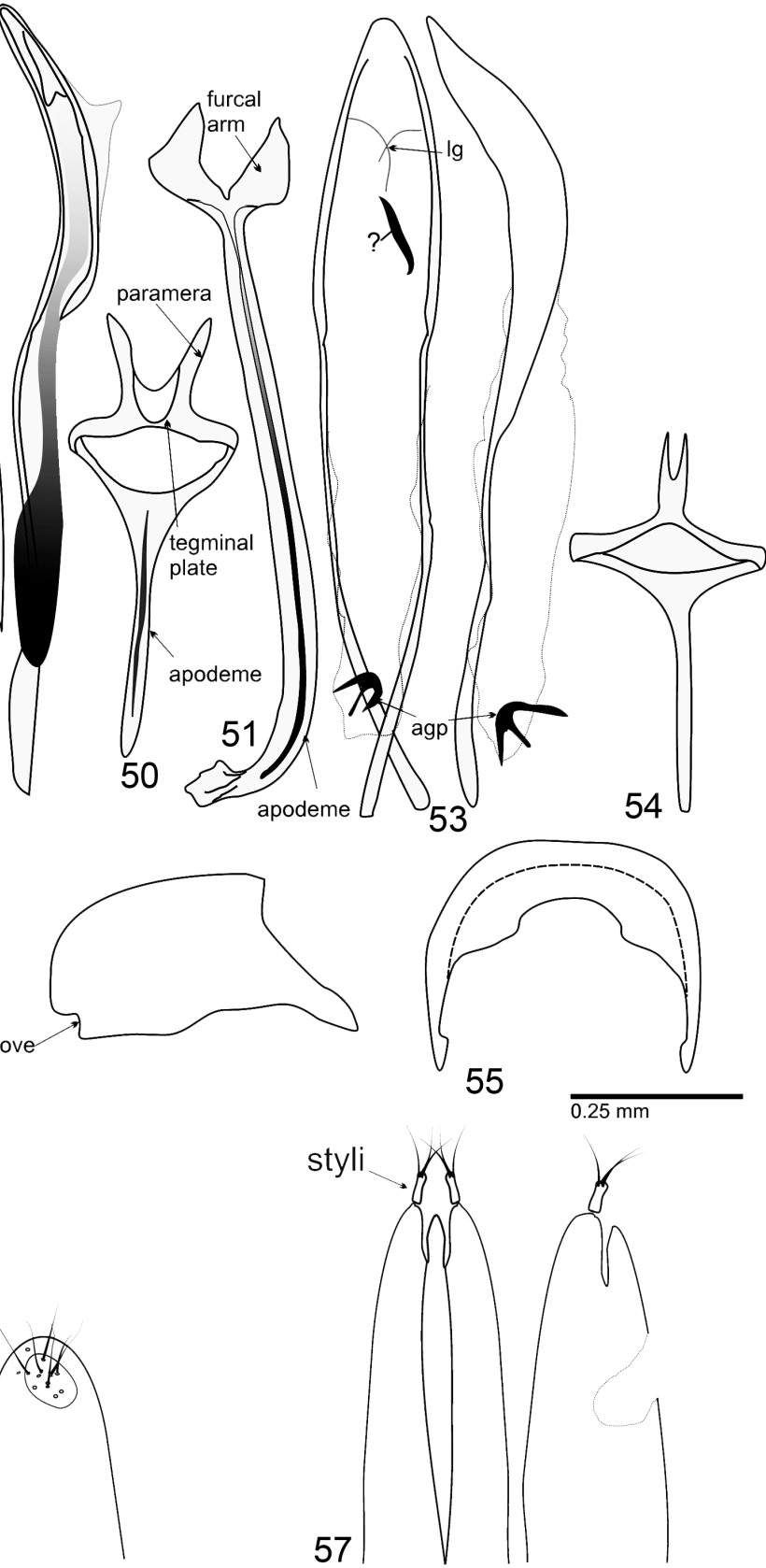

56

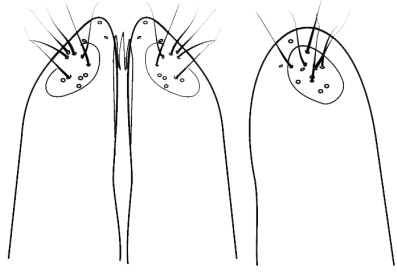

57

Figs 48-57: Sciaphilomorphus, Stasiodis and Wittmerella, male genitalia, male tergite VIII, and ovipositor. Sciaphilomorphus sulcirostris (CHEvr.): 48: aedeagus, dorsal and lateral views, 49: ligulae, 50: tegmen, 51: male sternite IX (spiculum gastrale), 52: tergite VIII, dorsal and lateral views. Stasiodis parvulus (F.): 53: aedeagus, dorsal and lateral views, 54: tegmen, 55: tergite VIII, dorsal view. Wittmerella viridisetosa Pes.: 56: apical part of ovipositor, dorsal and lateral views. Stasiodis parvulus (F.): 57: apical part of ovipositor, dorsal and lateral views. Abbreviations: agp - aggonoporium armature, lg - ligula. 